\title{
UNVEILING THE SOURCES OF WOMEN OPPRESSION: A STUDY OF THREE CASES
}

\author{
Minakshi Dutta \\ M.A, UGE-NET, \\ Alumni, Department of Political Science, Dibrugarh University, India
}

\begin{abstract}
In India women of different states, districts, villages and families are suffering from different sources of patriarchy. If someone is not allowed to work outside the home, someone is exploited at the work place and if someone is suffering because of her inability to give birth to a child, someone is suffering because of motherhood. Therefore, we cannot take all the women as a group to solve their problems as they are not suffering from same problems. In Assamese society women are suffering from different sources of patriarchy. These sources prevail from the folk lore to capitalism, motherhood to widowhood etc. Each and every woman are suffering from different factors. Therefore, it is very important to unveil and discuss these sources in order to change the society. Unless we determine the sources of women's oppression, we don't know who or what needs changing. In this case study an attempt is made to highlight certain major sources of oppression of women in Assamese society with special emphasize on family, motherhood, marriage and loyalty and capitalism. An attempt is also made to show how problems of all women are different from each other. The role of family in the process of gender socialization and the relationship between economic independence and empowerment of women has also been discussed. These sources were selected as they play a very dominated role in the systematic victimization of women which needs to be revealed.
\end{abstract}

Key words: Women Oppression, capitalism, widowhood, motherhood, economic, empowerment

Cite this Article: Minakshi Dutta, Unveiling the Sources of Women Oppression: A Study of Three Cases, International Journal of Management, 11(12), 2020, pp 1307-1314.

http://iaeme.com/Home/issue/IJM?Volume=11\&Issue=12

\section{INTRODUCTION}

Oppression is when a person or group of people abuse their power or social status in a burdensome, cruel, or unjust manner because of prejudices against those who below them. Oppression of women exists in every society of the world in different form from local customs to national policy decision. In every patriarchal society woman are treated as 
secondary sex or as 'others 'and not as human being who has subjectivity of her own. The status of women is not even near equal to men. No matter how much a society is developed, developing and underdeveloped, women always enjoys a secondary position in the society.

Many feminist thinkers have dealt with the sources of women oppression in a patriarchal society. According to them it is very important to determine the sources of women oppression in order to challenge the oppression of women. Marxists like Karl Marx, Hegel locates it to the economy and Alexandra Kollontai another Marxist locates it to the motherhood, sexuality, ideology of romantic love apart from economy. On the other hand, family is the key agent of oppression of women for Kate Millet. Liberal feminist like Marry Wollstonecraft, J.S. Mill emphasizes on legal inequality as a source of women oppression in society. Psychoanalytical feminist locates the role of subconscious mind in subordination of women.

Most of the feminist like Alexandra Kollontai, Julia Kristeva, Spivak are of the opinion that problems of all the women can never be same. Kollontai and Spivak rejected the concept of universal sisterhood. On the other hand, Kristeva rejected the categorization of women as a group which leads to the rejection of the particularity of the problem of each women.

\section{OBJECTIVES}

This paper is based on inter personal interview(unstructured) with 3 women of Assamese society and all of them are from different background. Separate interview has been conducted with all of them.

Hence, this paper aims to explore two main issues through narratives of 3 women of Assamese society:

- The factors or sources that systematically oppresses woman.

- The particularity of the problems of each woman.

\section{DATA ANALYSIS}

The narratives of the participants are analysed with the help of some theories put forwarded by feminist thinkers. For the purpose of this paper, the narratives of participants can be thematically divided as follows:

\subsection{Agencies of Socialization}

It is very important to study about the role of agencies of socialization as they are mainly responsible for educating people with gendered norms which creates exploitation of women. Socialization is a process through we learn how to behave in a way that is acceptable to the society. There are many agencies of socialization such as school, religion, peers, mass media etc. but family is the first and main agency of socialization.

A child is influenced mostly by his family environment. Parents, siblings and grandparents, plus members of extended family, all teach a child what he or she needs to know. The gendered norms and values are preserved by family. Kate Millet said family is the key patriarchal unit. It is the family that shapes the role, interest, choice of people. From the first case we show that it is the family who teaches the daughter of the women about her duties and goals in life. One day her daughter said that "Ma muk joldi biya diba, mur manuh tur ghorot dhei kahi bati dhubole pori ase. Moi nogole muk rickshaw tuli loi jabohi.' '(Mother give me marriage as soon as possible, I have a lot of plats to wash at my husband's home, otherwise he will come and take me in rickshaw ). The daughter always see her mother washing plates, cleaning home, performing triple responsibilities etc. and it made her think that the goal of life of a woman is to get marry and perform household works. Hence, she asked her mother to give marriage to her as soon as possible. This is how family 
both directly and indirectly teaches people gender roles. She observed her mother and assumed that cooking, cleaning etc. or household work is the primary task of women. But the gendered roles that a child learns from his or her family is further strengthened by other agencies of socialization such as school, peer group, mass media etc. Education holds the power to form understanding, attitudes and the behaviour of individuals. It is used as a tool for the promotion of national identities and can enhance the privilege of certain groups in the society, including men's power over women. Textbooks at elementary level are particularly crucial as they shape factual knowledge of skills that children are suppose to acquire, which can be different for girls and boys and can base their gender stereotyping. Moreover, the role of mass media is also immense in gender socialization. Different shows that are telecasted in Television has severe impact on the children. In TV serials also, women generally play the character of a bahu who takes all the responsibility of household work.

Apart from the agencies, according to Nancy Chodorow the socialization a girl and a boy educated with different gendered norms because of girl's continuous attachment with the mother and boy's separation from the mother. It is because of her attachment with the mother a girl inculcates all the values of mother. The six-year girl of the respondent spends most of her time with her mother and therefore she easily inculcates the values of her mother as her own value. When respondent's daughter became three years old, she was enrolled in a nearby play school. The respondent took the responsibility to teach her daughter at home and to ensure that she is doing her homework properly. When her daughter became 5 years old she was enrolled in the music, drawing and table tennis school and it is her who has the responsibility take her daughter to all these places. It is because of her attachment to her mother she cannot abject the identity of the mother without abjecting herself.

\subsection{Motherhood}

This section of the paper will deal with the notion of motherhood as a source of oppression of women.

The concept of motherhood enjoys central importance in the feminist studies as it is related to the oppression of women. In patriarchy motherhood is considered as one of the mysterious natural instinct of women. The motherhood is often equated with femininity and womanhood .People do not acknowledge that the mother is also a women and all women are not mother . Since only women has the capacity to give birth to a child or to be a mother it is assumed the only mother has the responsibility to ensure moral and physical development of the child . Sometimes the responsibility of child rearing may become burden for the mother specially in case of a working mother and sometimes a woman may not be interested in performing the responsibilities of child rearing. Feminist theorist like Alexandra Kollontai claims that the concept of motherhood does not necessarily mean that mother always has to be with their child all the time and take the responsibility of moral and physical development. She argued the essence of every individual is his or her capacity to creatively engage with nature and anything that deprives people (women) to creatively engage with nature or to exercise her right to labour should be oppose.

From the findings of the first case it came to know how the concept of motherhood makes women to take double responsibility. Although the respondent is economically independent woman, participates in the public sphere but she could not make herself free from the responsibilities of a mother. On the other hand, her husband is completely free from child rearing. She herself stated that she loves to take care of her daughter but here the questions come why does she loves to bear the double burden and what makes her to perform the socalled duties of a mother and what makes her husband free from the child rearing responsibility. It is the capacity of the women to become a mother or to give birth to a child 
or the different role of men and women in the process of reproduction is responsible for such divisions in the responsibility. The simple biological difference between men and women is use to create further differences in the roles of men and women. From the very childhood both men and women learn their roles and duties in life. People believes that since women has the capacity to give birth to a child and breast feed her child, society makes women to take the entire responsibility of child rearing. Such understanding makes people to think that child rearing is the primary duty of a mother. Moreover, according to Nancy Chodorow, a girl is more attached to her mother in comparison to a boy and the separation of mother and the daughter takes place only after the marriage of the daughter but than daughter herself develops interest to perform the role of a mother. This may be the reason why the respondent held that she loves to perform the responsibilities of a mother.

Another question also comes why the respondent is working as a teacher of L.P school instead of having a professional degree. It is not just the question of underemployment but it is the concept of motherhood that stops her from utilizing her degree or talent. If she wishes she can seat for other interviews that needs professional degrees. But she is working as a school teacher which was not her dream job just because this job allows her to make her time for her daughter. This means the notion of motherhood again makes women to sacrifice her dreams or to engage her creatively with nature. Therefore, we can say that economic independence of women may not lead to the empowerment of women.

To deal with the problems created by motherhood towards the development of a woman Julia Kristeva has provided certain solution. According to her women should not reject maternity. It is nothing wrong in giving birth to a child. But maternity should be separated from motherhood. The ideas associated with motherhood that restricts the free movement of women should be challenged but the whole concept of maternity should not be abandoned. Thus, we can conclude that motherhood should not be taken as the exclusive responsibility of a woman. Since motherhood is all about taking care of a child anyone can perform this responsibility.

\subsection{Economic Independence and Empowerment of Women}

This section of the paper will deal with the relationship between economic independence and empowerment of women.

People assumes that economic independence of a women always leads to her empowerment. In certain cases, this assumption may not be true. Therefore, it is very important to discuss the relationship between these two factors.

J.S Mill held that even if women come out from their homes and works in the public sphere she would not be able to make herself free from the domestic responsibilities and responsibilities of being a mother or he is of the opinion that economic independence does not make women free from her so-called traditional role. In the first case this assumption of Mill appears to be correct where the respondent has failed to make herself free from the domestic responsibilities even after being economically independent. The women in the first case works as a teacher in a school but she still accepts the household responsibilities without any question. On the other hand, her husband who also works in a bank performs no domestic duties. She cooks rice for her and roti for her husband and in laws before leaving to school. Even after coming from her job she has to cook dinner, wash and press cloths of her husband and to clean home. To make some free times for herself and her daughter she hired a female domestic help only for Sundays but her mother in law was not ok with her decision and that is why she stopped the domestic help to come.

However, we cannot agree with Mill who intended to establish that since women cannot make herself free from the domestic responsibilities, she should not come out from home to 
work in the public or to take the double burden. Jennifer Ball suggests that in order to make working women free from the burden of domestic work, there should be either commodification of the domestic duties or women should share domestic responsibilities with her husband.

Here the question comes why economic independence do not always make a woman empowered or do not make her say no to domestic responsibilities. It again may be because of biological determinism which creates differences in the role of men and women in other aspects of life also. There also exist a kind of power relations because of which the respondent cannot say no to her domestic duties. The constructed power relationship that exist between the respondent and her husband and respondent and her mother in law is making her to take triple responsibilities - as housewife, mother and as a teacher. This hierarchical relationship that exist between male and female or between elder women and younger women, between elder man and younger man is the main reason oppresses the so called inferior. This power relationship or hierarchical relationship is based on psychosocial feelings of superiority of the exploiter and the inferiority feeling of the exploited. The respondent accepts domestic responsibilities as her responsibilities because of the psychological feeling of inferiority and because of this inferiority most of the women cannot oppose their so-called responsibilities of household even after becoming economically independent. Therefore, the study of politics should not merely confine to the study of formal power structure. It should concern about the informal power relations that existed between people along with the formal power structure. Only then the real sources of exploitation of people could be revealed.

\subsection{Patriarchy and Capitalism}

This section of the paper will deal with the relationship between patriarchy and capitalism and how capitalism promotes the idea of "beautiful women".

The oppression of women is very ancient: it existed before capitalism. The women's movement developed in different parts of the world challenged the traditional belief system which were anti -women and as a result states extended legal rights to women. However, this does not mean that traditional belief system has ceased to be exist in all the societies. Still number of practices are there in the name of tradition that exploits women. But the thing is that this traditional patriarchal value system is not legal. In a modern society people cannot publicly praise these traditional values. For example, no one can legally stop a woman of a modern society to enter in to a temple. However, Capitalism has given birth to a legal patriarchy which reinforced the traditional patriarchal values. Capitalism and other forces of globalization reinforced and strengthened the differences of role between men and women.

In first case the nexus between patriarchy and capitalism can also be seen. Here the 6year-old daughter of the women always prefers to wear long frocks with matching hair accessories, mascara, eyelashes, lipstick etc. and that too from an expensive mall in the town. She also has a good collection of barbie toys. The outfits like long frocks, hair accessories etc. gendered products and all these are making available by the malls - the capitalists. The interests of the daughter of the respondent towards long frocks lipstick, mascara etc. is an example of how capitalism is promoting the concept of "beautiful women". Few years back when there was no or less shopping malls in the town, the children of that time did not demanded for long frocks, lipsticks etc. and hence they were not very much conscious about their looks or dresses. But now the designers are creating more differences between the cloths of boy and a girl.

Apart from dresses, other products such as different toys manufactured for boys and girls also promotes the concept of "beautiful woman". The barbie doll is considered as for girls and Ken doll is considered as toy for boys. The barbie is a fashion doll which is a tall, slim and 
fair doll with long flowing hair and a disproportionately large head (in relation to the rest of her body). Barbie is the perfect image of daintiness. A girl from her very childhood wants to look like a barbie and boy's wants to look like Ken who featured a dimpled smile, a head could swivel, bent arms. a more muscular physique. This leads to the rejection of the bodies which are not identical to the image of the barbie. Women even opt for the cosmetic surgeries to look like a barbie or to look beautiful. Thus, we can say that capitalism leads to the rejection of the natural bodies of women.

Apart from promoting the concept of "beautiful woman", capitalism reinforced the objectification of women. In commercial advertisement the body of women is projected as a commodity. However, all these are very much legal. Manufacturing different fancy dresses and toys for girls and boys, unnecessary projection of women in cinema, televisions and commercial advertisement is very much legal and hence it is more dangerous than traditional patriarchy.

\subsection{Marriage}

This section of the paper will deal with the concept of marriage.

Feminist often considers marriage as patriarchal because of the power structure associated with the institution where men assumes the role of ruler and female of the ruled. Within the institution of marriage, the relationship between men and women is not that of partners but of husband and wife. The term husband has been derived from old Norse husbondi, where hus means house and bondi means to conserve resources and use them frugally. That means husband is the owner of all the resources including women. Therefore, marriage is often characterised by inequality between sexes, oppression of women by man etc. The oppression need not to be always physical violence. It can be epistemic violence also i.e oppression and subordination caused by knowledge and thought associated with female gender that they are perfect for mothering or born to be a mother etc. In the first case the knowledge associated with motherhood made the respondent to take double burden. The relationship between her husband and her is not of partnership as there is no equal sharing of responsibilities.

Apart from all these things the institution of marriage demands undivided loyalty and love from women but not from men . The wife has to show continuous loyalty to her husband. The wife has to show her loyalty or should consider herself as belong to her husband even after his death. In the case 3 it can be seen that the widow was victimized because of having an affair with other men. She entered into a physical relationship with her niece and became pregnant. She fled with her niece but he abandoned her. Few months later she gave birth to a girl but the baby girl died. She became an evil in the eyes of everyone. After few months her niece returned to his home and his family (parents and wife) accepted him. Even neighbours and other people of the village did not question on his character. All they wanted from him was to break all the ties with the widow and after breaking his connections with her, he became a good man for the society. But the life of the widow became no less than hell. Some women from her village went to the Deputy Commission and requested him to rusticate her from her job but they failed. After all these she decided to join the school again where she works as an Anganwadi worker and to start a new life. One day she went to the school but she had to face moral policing. Some of the women attacked her in front of her school and they tried to tear her cloths and made her almost half naked. She faced both verbal and physical assault. But the men with whom the widow had an affair was accepted by his wife and family as well as by the society. His loyalty was not questioned. He did not face and kind of violence as faced by the widow. She was a widow and has no one to cheat in her marriage but the man with whom she had an affair cheated his wife. Which means that society allows men to have extra marital affairs but women cannot enter into a physical relationship with other men even after 
the death of her husband. As Alexandra Kollontai stated the sexual life of men is always separated from his character but in case of women her sexual life decides her character. Women's personality, her character is always based on her sexual life. Her sexual relations determine what kind of person she is. Society always expect women to belong to her husband even after his death. But in case of men such restrictions cannot be strongly seen.

Alexandra Kollontai was of the opinion that in a patriarchal society material consideration determines the marriage. In ancient times it was loyalty to kinship and collective material interest determined the marriage. In feudalism it was the family business interest that determined the marriage. But in capitalism the concept of monogamous love became basis of marriage which demanded undivided love and loyalty of women to ensure inheritance within the family. Although Kollontai argues for monogamous love but still the dominance of material interest within the institution of marriage can be seen. In the case 2 the girl wanted her friend to marry a settled man and to leave her jobless boyfriend. Such statement or opinion of the respondent also shows how patriarchal concept of male bread winner can be stressful for man. Someone would be chosen and rejected on the basis of his bread winning capacity. Such ideas also make marital relationship unhappy. One man is compared with other men on the basis of his capacity to earn. This also makes men to think that since women do not earn and stays at home, things related to money and all other things related to public life cannot be discussed with her. This prevents marital friendship. Wives economic dependent on her husband may create women's subordination. This may confine women within the four walls of the home and make her associated with motherhood and marriage. The economic dependence not only creates burden for men but also creates relationship between ruler and the ruled. Therefore it is very important for women to get herself educated and economically independent to have full control over her own body and mind.

\section{CONCLUSION}

From the above discussion we come to know that how family, motherhood, marriage and capitalism can be dangerous for women. As mentioned earlier it is very important to discuss the sources of women oppression as only then we can understand what needs to be changed. The problem lies in the fact that most of the times people do not even realise that their lives, choices, goals etc are determined by the system or ideology called patriarchy. As Antonio Gramsci said the dominant group in the society rules or exploits other people not only through coercion but also through creation of ideology or worldview very tactically that people do not even realise that their common sense is guided by any ruling ideology. That realization is very important to make their voices heard. Although feminists are continuously questioning and criticizing all these above-mentioned sources of women oppression but the voices of victims are unheard. They are represented by others. That realization is very important to bring about changes in the society. Education can play a very important role in this situation. Not only women but everyone should be educated to bring about changes and to establish a new society based on sensitivity, equality and mutual respect. True and meaningful education should be provided from the very childhood. Marry Wollstonecraft also stated that the period of childhood is very sensitive. The things learned in this phrase of life remains in the subconscious mind. It is very difficult or impossible to change a person later phrases of his life if his personality has moulded by patriarchal values in the childhood. Moreover, the independence of both mind and body is important to make women empowered and education serves this purpose also. Education helps women to shape the goals and choices of her life as well as to control her body. 
The aim of the education is not about final triumph over patriarchy but about gradual transformation of social field so decisively that equality and independence prevail everywhere.

\section{REFERENCES}

[1] Smith, Sharon(1997), 'Engels and the Origin of Women's Oppression', International socialist Review, pp.1-13

[2] Ball, Jeniffer (2001), 'J.S. Mill on Wages and Women: A Feminist Critique', Review of Social Economy, Vol. LIX, No.4

[3] Menon, Nivedita (2012), 'Seeing Like a Feminist', Penguin Books limited.

[4] Mill, J.S, 'Speech of The Late', viewed 20 November, 2019 $<$ https://www.jstor.org/stable/40549820?seq=)

[5] Powell, Jim (1996), 'Equal Rights for Women: The Contribution of Mary Wollstonecraft', viewed 24 November 2019, < articles://fee-org.cdn.ampproject.org/v/s/fee.org)

[6] Spival,Gaytri (2010), 'Can Subaltern Speak: Reflections on the History of an idea', viewed 21 November 2019, <https://www.jstor.org/stable/10.7312/morr14384

[7] Condit, Tom, 'Alexandra Kollontai', viewed 21

November, $<$ https://www.marxist.org/archive/kollontai/into.htm 